Finally, then, for $D>0$,

$\varkappa=\frac{A}{2 \sqrt{ }(C D)} \ln \frac{V C-V D}{V C+V D}-A \int_{0}^{\left(2 x_{0}-1\right)} \frac{d x}{\left(C x^{2}-D\right)}+\int_{0}^{1} G(x) d x$.

Nilsson (1957) has suggested a simple formula for $\varkappa$ derived by taking the mean values of each of the terms in the numerator and denominator of equation (2) separately:

$$
\varkappa_{\text {appr. }}=\frac{\frac{1}{5} b_{1}\left(C_{11}+C_{12}\right)+C_{44}\left(2 C_{11}+C_{44}\right)}{\overline{1} \frac{1}{105} b_{1}^{2} b_{2}+\frac{1}{5} b_{1}\left(C_{11}+C_{12}\right) C_{44}+C_{11} C_{44}^{2}} .
$$

Table 1 shows a comparison between the values of $\varkappa_{\text {appr }}$ and $*$ obtained by numerical integration of equation (5) at intervals of 0.05 in $x$. The elastic constants used were those given by Flinn, McManus \& Rayne (1960) for well ordered $\mathrm{Cu}_{3} \mathrm{Au}$. Of course, for other than monoatomic systems, alloys (such as $\mathrm{Cu}_{3} \mathrm{Au}$ ) or compounds of atoms of different masses, this correction does not take into account the more complex nature of the vibrational spectra. At the present time though, this is not possible and the type of correction discussed here is all that is presently feasible. The comparison of the two calculations in Table 1 shows the type of error that might occur, even with a monoatomic crystal.

It is clear that the exact formula, equation (5), should be used for the case $D>0, D / C<1$. By contrast, Nilsson
Table 1. $x$ for ordered $\mathrm{Cu}_{3} \mathrm{Au}$

$$
\begin{gathered}
\varkappa(10)^{12} \\
\mathrm{~cm}^{2} . \text { dyne }^{-1} \\
\text { (equation (5)) } \\
3 \cdot 12 \\
3.91
\end{gathered}
$$
Error (\%)
$+38 \cdot 4$
$+18 \cdot 2$

(1957) showed that for $\mathrm{KCl}$ and $\mathrm{NaCl}$, for which $D<0$, the agreement was within a few percent.

The author is indebted to Prof. I. Stakgold who suggested the mathematical technique for evaluating equation (4) and to Mr P. Gehlen who wrote the program for the numerical integration. He further wishes to express his appreciation to Prof. J.B. Cohen for his encouragement in this work.

\title{
References
}

Chipman, D. R. \& Batterman, B. W. (1963). J. Appl. Phys. 34, 912.

Chipman, D. R. \& Paskin, A. (1959). J. Appl. Phys. 30, 1992, 1998.

Flinn, P. A., McManus, G. M. \& Rayne, J. A. (1960). Phys. Chem. Sol. 15, 189.

Nilsson, N. (1957). Ark. Phys. 12, 247.

\section{Notes and News}

Announcements and other items of crystallographic interest will be published under this heading at the discretion of the Editorial Board. The notes (in duplicate) should be sent to the General Secretary of the International Union of Crystallography (D. W. Smits, Rekencentrum der Rijksuniversiteit, Grote Appelstraat 11, Groningen, The Netherlands). Publication of an item in a particular issue cannot be guaranteed unless the draft is received 8 weeks before the date of publication.

\section{Reǵinald William James, 1891-1964}

Sir Lawrence Bragg writes: R. W. James, who died in Cape Town on 7 July 1964, was one of the pioneers of $\mathrm{X}$-ray crystallography. James graduated with first-class honours in Physics at Cambridge in 1912 and for two years carried out research in the Cavendish. In 1914 he was invited by Sir Ernest Shackleton to join his antarctic expedition as physicist, and when the Endurance was crushed by the ice and the party returned to England after its rescue, James joined the experimental Sound Ranging Section for locating enemy guns which had been established in Belgium under W. L. Bragg. Their close association in their war work naturally led to James joining Bragg at Manchester in 1919 when the latter was appointed Professor of Physics there. It was in this way that James entered the field of research in which he was to work for the rest of his life. He collaborated with Bragg and Bosanquet in the series of 'B.J.B.' papers from 1921 onwards which established the quantitative measurement of X-ray diffraction. Darwin had formulated the theory for perfect and imperfect crystals, and the intensive study of diffraction of sodium chloride as a standard 'mosaic' crystal, in particular the comparison of the integrated reflexion with the intensity of the incident beam, established the use of absolute values of $F(h k l)$ in X-ray crystallography. Two developments stemmed from this work. On the one hand James and his colleagues made a profound study of atomic scattering factors and the influence of thermal movements (Debye effect) and the quantitative measurements culminated in the well known paper by James, Hartree \& Waller in which the zero-point energy was directly measured. On the other hand, absolute $F$ values provided crystallographers with a means by which far more complex crystals could be tackled. James and Wood were responsible for one of the earliest of these investigations, the structure of barium sulphate, which has eleven parameters. This marked a great step forward at a time when it was widely doubted whether crystals with more than two parameters could be analysed with significant results. James's work at Manchester centred round the theory of $\mathrm{X}$-ray diffraction and accurate quantitative measurement. His book The Optical Principles of the Diffraction of X-Rays, published in 1948, has a world-wide recognition as the standard text book on the subject.

In 1937 James was appointed Professor of Physics 
in the University of Cape Town. He built up an active research school; the main interest of his pupils (one of them is A. Klug, well known for his work on virus) lay in the field of complex organic compounds.

James was a fine lecturer and a polished writer. Towards the end of his time at Cape Town he became involved in administrative work, and for a year served as Acting Principal and Vice Chancellor. Although teaching and research were always his main interests, he had a high reputation amongst his colleagues for his sane judgement in university affairs. He was elected a Fellow of the Royal Society in 1955.

\section{Chromatic focusing of $\mathbf{X}$-ray diffraction lines}

Cameras with chromatic focusing are useful in certain studies of X-ray line broadening. The method has been developed particularly by Professor Jan Cermák, who can supply descriptions of the experimental details and nomograms for finding optimum focusing conditions on request. His address is Ústav Fyziky Pevných Látek, Praha 6, Cukrovarnická 10, Czechoslovakia.

\section{International Union of Crystallography Commission on Crystallographic Apparatus}

\section{Single-crystal Intensity Project}

Currently there is considerable activity both in the collection of extensive single-crystal $X$-ray data and in the methods of attaining high accuracy in the measurement of intensities of individual reflexions. This interest led to the Open Sessions of the Commission at the Sixth International Congress of the Union at Rome, September 1963, on 'Automatic Single-Crystal Diffractometers for X-rays and Neutrons'. The Open Sessions did not, however, treat questions of accuracy in the measurement of intensity, which is of considerable importance for a variety of reasons, such as the determination of precise atomic parameters, of the detail of atomic and molecular vibrations and of the location of electron redistribution arising from bonding. It would therefore be useful to arrive at a valid measure of the accuracy which can be expected from counter measurements. This cannot be achieved completely from measurements on a single assembly of any one type which would yield only a measure of internal accuracy. Assessment of measurements on a standard compound on a variety of single-crystal diffractometers preferably of different designs will be required. In this way, variation directly attributable to basic design may be assessed. To carry out such a proposal effectively, it will be necessary to gain the cooperation and assistance of many crystallographers throughout the world.

To contribute to the clarification of this situation, it is proposed that the Commission on Crystallographic Apparatus organize such a project as part of its activities during 1963-66. Plans have been completed as to the simple procedure to be followed.

It is intended that the participants will carry out the measurements by the method normally followed in their laboratory. Only the standard material (organic) and the range of reflexions selected for measurement will be specified.

Dr S. C. Abrahams (Bell Telephone Laboratories Inc., Murray Hill, New Jersey 07971, U.S.A.) is the Commission member responsible for this project with the assistance of Dr D. C. Phillips and Professors Y. Saito and M. M. Umanslky. Those desirous of participating in the project should contact Dr Abrahams for a supply of the standard material and copies of the questionnaire and data sheots.

We would be grateful for the cooperation of any crystallographer equipped to carry out the measurements with a hand-set or automatic diffractometer. The greater the number, the more significant will be the conclusions of the project. Cooperation in the project offers the opportunity to gain an objective assessment of your own assembly.

It is intended that the numerical treatment of the data will be handled by Dr W. C. Hamilton.

\section{Book Reviews}

Works intended for notice in this column should be sent direct to the Editor (A.J.C. Wilson, Department of Physics, University College, Cathays Park, Cardiff, Great Britain). As far as practicable books will be reviewed in a country different from that of publication.

\section{Systematische Klassification der Massenge- steine. Par F. RonNer. Wien: Springer-Verlag, 1963.}

L'auteur nous présente une classification minéralogique quantitative modale des roches ignées. Il n'a pas employé le terme 'Eruptivgesteine' afin d'éviter toute idée génétique, et utilise le terme 'Massengesteine' afin de ne pas laisser de côté d'éventuelles migmatites non gneissiques. Il essaye de concilier la classification de Johannsen, trop rigide, et la nomenclature de Tröger, tout en se réclamant surtout de Rosenbusch.
Dans la première partie, nous trouvons un exposé critique des principes de classification, et nous aboutissons à la définition de 39 familles associées en 7 groupes:

roches quartziques, 1 famille;

roches quartzo-mafiques, 1 famille;

roches quartzo-feldspathiques, 5 familles;

roches feldspathiques, 15 familles;

roches feldspathiques et feldspathoïdiques, 5 familles; roches feldspathoïdiques, 4 familles;

roches mafiques, 8 familles.

Chacun de ces groupes se situe graphiquement dans 